\title{
Benthic-pelagic exchange of microalgae at a tidal flat. 2. Taxonomic analysis
}

\author{
Cathy H. Lucas*, Clare Banham, Patrick M. Holligan \\ School of Ocean and Earth Science, University of Southampton, Southampton Oceanography Centre, European Way, \\ Southampton SO14 3ZH, United Kingdom
}

\begin{abstract}
Benthic-pelagic exchange of diatoms over a tidal cycle has been examined using a combination of field measurements and annular flume experiments. The relative contribution of benthic and planktonic species to water-column abundance and biomass has been estimated using taxonomic counts, and cell volume to carbon conversions. In June, peaks in chlorophyll a (chl a) biomass occurred either side of the high-water slack period, which corresponded with increased abundance of benthic diatoms, as well as the large centric diatom Coscinodiscus spp. In numerical terms, benthic diatoms accounted for, on average, 15 to $42 \%$ of total diatom abundance over the flood-ebb period, while Coscinodiscus spp. accounted for 12 to $17 \%$ in June and $3 \%$ in late August. Because of the large size of planktonic forms (e.g., Coscinodiscus spp., Rhizosolenia spp., Biddulphia spp.) compared with the small benthic Nitzschia and Navicula species, the contribution of benthic diatoms was significantly lower in terms of biomass. The average contribution of benthic diatoms to total diatom carbon was $<1 \%$ in June, but up to $25 \%$ in late August. In contrast, the relative contribution of Coscinodiscus spp. was $~ 90 \%$ in June and 73 to $80 \%$ in late August. The flume experiments confirmed that, in addition to increased benthic abundance in response to stepwise increases in current velocity, the large centric diatom Coscinodiscus spp. was also resuspended from sediments at high current velocities. At low current velocities, these cells rapidly sank to the seabed, the rate probably enhanced by deposition of sand grains out of the water column. Ecological implications related to water-column biomass and production, macro-infauna diet, and composition of benthic chl a are discussed.
\end{abstract}

KEY WORDS: Resuspension · Sinking - Benthic diatoms · Phytoplankton · Coscinodiscus spp. · Annular flume Resale or republication not permitted without written consent of the publisher

\section{INTRODUCTION}

Variability in phytoplankton (including suspended benthic microalgae) biomass and community composition is generally measured at time scales of weeks to months (i.e., spring-neap and seasonal cycles) and over spatial scales of metres to kilometres. However, short-term (i.e., hourly) and small-scale (i.e., centimetre to metre) variability can also be significant (Harris 1980), particularly in estuarine environments (Roman \& Tenore 1978, Cloern et al. 1989, Lucas et al. 2000). Such changes are brought about by both biological and physical mechanisms. Seston depletion in the benthic boundary layer above dense mussel beds has been

*E-mail: catherine.h.lucas@soc.soton.ac.uk reported by Fréchette \& Bourget (1985), Asmus \& Asmus (1991), and Muschenheim \& Newell (1992). Physical factors affecting phytoplankton distribution include tidal fronts and advection, local turbulence, wind-driven currents (see Cloern et al. 1989), and resuspension of microphytobenthos, in particular benthic diatoms, by tidal currents and wave action (de Jonge \& van Beusekom 1995).

The presence and importance of benthic diatoms as temporary members of the phytoplankton is a wellknown phenomenon (Grøntved 1949, Cadée \& Hegeman 1974, Baillie \& Welsh 1980, Demers et al. 1987, de Jonge \& van Beusekom 1992, 1995). In shallow estuaries, much of the spatial variability in chlorophyll a ( $\mathrm{chl}$ a) concentration has been reported to be the result of resuspended benthic cells (Shaffer \& Sullivan 1988). 
For example, de Jonge \& van Beusekom (1992) calculated that benthic diatoms contributed up to $60 \%$ to total water-column biomass in the Ems estuary. In the vast majority of these studies, however, only temporal and spatial changes in total chl a biomass have been examined (Wainwright 1990, de Jonge \& van Beusekom 1992, 1995), with community composition generally not being considered.

When used alone, chl a does not provide any information on the types of cells that are being redistributed across the sediment-water interface. Those studies that have included taxonomic enumeration have tended to focus solely on the resuspension kinetics of benthic diatoms (de Jonge \& van den Bergs 1987), while studies that have identified small-scale vertical changes in both planktonic and benthic constituents are extremely scarce (Hummel 1985, Delgado et al. 1991). Planktonic diatoms, which tend to dominate in shallow, turbulent environments such as estuaries, tend to sink when turbulence is low (Smayda 1970, Smetacek 1985, Kiørboe 1993), and can therefore undergo cycles of suspension and settling through the water column. The potential significance of this process on the feeding preferences of benthic deposit and suspension feeders is considerable (Herman et al. 2000).

As part of the ECOFLAT Project carried out at the Molenplaat tidal flat in the Westerschelde estuary (SW Netherlands), benthic-pelagic exchange of microalgae has been examined using a combination of field measurements and annular flume experiments. Quantitative and qualitative changes in chl $a$ and accessory pigments have already been described, together with estimates of the percentage of sedimentary biomass lost from tidal flat sediments during resuspension events (Lucas et al. 2000). It has been established that diatoms dominate both the benthic (Lucas \& Holligan 1999) and pelagic (J. Kromkamp pers. comm.) microalgal communities. This complementary paper presents results from diatom taxonomic analysis of water samples collected during the field and flume measurements. The relative contributions of benthic and pelagic diatoms to water-column biomass have been estimated from cell counts and cell volume to carbon conversions.

\section{MATERIALS AND METHODS}

Study area. The Westerschelde estuary (SW Netherlands) is a turbid and eutrophic, well-mixed coastal plain estuary $\sim 100 \mathrm{~km}$ long. In spite of the high nutrient load, net pelagic photosynthetic production is relatively low due to the high turbidity in the water column (Kromkamp et al. 1995). The Molenplaat tidal flat (ca $1.5 \mathrm{~km}^{2}$ ), situated in the mid-region of the estuary, has a wide diversity of sedimentological and biological properties (Herman et al. 1999, Lucas \& Holligan 1999, Moens et al. 1999).

During ECOFLAT, 4 field campaigns were carried out at 5 sites on the Molenplaat as follows: 1 (28 May-7 June 1996), 2 (27 August-5 September 1996), 3 (2-13 June 1997), and 4 (1-12 September 1997). The choice of sampling sites was based on a detailed spatial and temporal survey carried out in 1995. In terms of mean grain size, the sites rank as $2<1<3<4<5$. The centrally located Site 2 is characterised by a well-developed diatom mat, a macrofauna community dominated by suspension feeders, and high thresholds of erosion (Lucas \& Holligan 1999, Widdows et al. 2000). Sites 4 and 5 at the edge of the tidal flat are sandy, and have a low microphytobenthos biomass (Lucas \& Holligan 1999) resulting in a mobile bed prone to bedload transport at high current speeds. Sites 1 and 3 are intermediate in nature. The deposit-feeder Macoma balthica is abundant at Sites 1,2,3 and 4 .

Annular flume experiments. The Plymouth Marine Laboratory (PML) annular flume was used to quantify sediment erodability and microalgae resuspension on board a Rijkswaterstaat ship moored on the Molenplaat. A detailed description of the design and operational procedures is given in Widdows et al. (1998a,b), with collection of sediments and experimental procedures specific to the Molenplaat experiments described in detail in Widdows et al. (2000). Briefly, the measurement of material flux across the sedimentwater interface was carried out in 2 phases. During Phase I (30 to 40 min duration), clearance and biodeposition rates of particles from the water column was measured at a current velocity of $5 \mathrm{~cm} \mathrm{~s}^{-1}$. Phase II (150 min duration) quantified suspended particulate matter (SPM) concentration $\left(\mathrm{mg} \mathrm{l}^{-1}\right)$, mass of sediment eroded $\left(\mathrm{g} \mathrm{m}^{-2}\right)$, and sediment erosion rate $\left(\mathrm{mg} \mathrm{m}^{-2} \mathrm{~s}^{-1}\right)$ in response to a stepwise increase in current velocity from 10 to $50 \mathrm{~cm} \mathrm{~s}^{-1}\left(5 \mathrm{~cm} \mathrm{~s}^{-1}\right.$ increments, 15 min duration each). The experiments were duplicated for each site examined. Analysis of covariance (ANCOVA) based on regressions between the log of sediment mass eroded and current velocity revealed no significant differences between replicates (Widdows et al. 2000). Although reproducibility was slightly less significant on a chl a basis due to the patchy nature of microalgal mat resuspension, duplicate experiments were still highly comparable.

Microalgae resuspension was measured at all 5 sites during the Phase II experiments (10 to $50 \mathrm{~cm} \mathrm{~s}^{-1}$ ), with the final measurement of Phase I $\left(5 \mathrm{~cm} \mathrm{~s}^{-1}\right)$ used as a Time $_{0}\left(T_{0}\right)$ (Lucas et al. 2000). In June 1997, an additional flume experiment was carried out using sediment from Site 4 . Unlike the previously described experiments, the temporal sequence of current velocity 
simulated concurrent in situ measurements of the tidal cycle at Site 4. For chl a (1996 and 1997) and HPLC pigment (1997) analyses, 50 to $100 \mathrm{ml}$ of water was collected from $\sim 5 \mathrm{~cm}$ above the test bed, and filtered through Whatman GF/C filters (pore size $1.2 \mu \mathrm{m}$ ). Two to 3 drops of $\mathrm{MgCO}_{3}$ were added to prevent acidification of the filters, after which they were folded and frozen at $-70^{\circ} \mathrm{C}$ until analysis. Water samples for diatom identification and enumeration were collected in 50 to $100 \mathrm{ml}$ brown bottles and preserved with 2 to 3 drops of Lugol solution.

In situ seston dynamics. In May-June 1996 (Sites 2,3,4,5 and gully) and August-September 1996 (Sites 2,4), samples for SPM and chl a analyses, and diatom identification and enumeration were collected over a flood-ebb period lasting 4 to $5 \mathrm{~h}$. Water was collected every 10 to 30 min using submersed pumps fixed to a post at $30 \mathrm{~cm}$ intervals ( 5 to $215 \mathrm{~cm}$ above the seabed). Data from 5 to $95 \mathrm{~cm}$ depth are presented in this paper. Details of SPM collection and analysis are given in Lucas et al. (2000). For chl a analysis, 50 to $100 \mathrm{ml}$ of water was filtered and frozen using the technique described for the flume experiments. In August to September 1996, additional samples for HPLC analysis were collected in a similar manner, from the lowest (5 $\mathrm{cm}$ above seabed) and uppermost (35 to $215 \mathrm{~cm}$ from seabed) pumps at each sampling interval. For all sites, depths and times, water samples for diatom identification and enumeration were collected in 50 to $100 \mathrm{ml}$ brown bottles and preserved with 2 to 3 drops of Lugol solution.

$\mathrm{Chl} \boldsymbol{a}$ and accessory-pigment analyses. $\mathrm{Chl} a$, phaeopigments, and accessory pigments were measured using a combination of fluorometry and ion-pairing, reverse-phase HPLC with a $5 \mu \mathrm{m} \mathrm{C}-18$ column-a modification of the method of Mantoura \& Llewellyn (1983) described by Barlow et al. (1993). Samples for both procedures were extracted in $90 \%$ acetone, ultrasonicated for $30 \mathrm{~s}$, and centrifuged at $3000 \mathrm{rpm}(2000 \times$ $g$ ) for $15 \mathrm{~min}$. Details of these procedures are given in Lucas \& Holligan (1999) and Lucas et al. (2000).

Where HPLC pigment data were available, the phylogenetic group-specific contribution to total chl a biomass was determined using multiple linear regressions. The resulting chl a:accessory pigment ratios were multiplied by the relevant marker pigment to calculate the relative abundance of each group. Marker pigments include fucoxanthin (fuco) for diatoms, chlorophyll $b$ (chl $b$ ) for chlorophytes, peridinin (perid) for dinoflagellates, and 19'-hexanoyloxyfucoxanthin (19'-hexa) for prymnesiophytes. This procedure provides an independent estimation of the relative contributions of different groups to total biomass, and allows greater accuracy in relating cell counts and carbon to total chl a biomass.
Diatom identification and cell-carbon conversion. Microscopic examination of the Lugol-preserved water samples was carried out to determine the relative contributions of pelagic and benthic diatom species. Each sample was thoroughly mixed before a known volume was transferred into a settling chamber and prepared for examination using Utermöhl's sedimentation technique. Where necessary, the samples were diluted with distilled water. The settling chambers were scanned at both $100 \times$ and $200 \times$ magnification using an inverted light microscope (Leica DMIRB) fitted with phase contrast, brightfield, and polarized illumination. Both 'live' cells (i.e., containing chloroplasts) and diatom frustules were identified, with between 100 and 500 live cells counted per sample. Initial tests revealed that this protocol produced reproducible results.

Diatom abundance was expressed in no. cells $\times 10^{3}$ $\mathrm{l}^{-1}$. For the dominant taxa, cell numbers were converted to cell carbon using estimates of biovolume (reviewed by Hillebrand et al. 1999) and the diatom cell volume (V) to carbon (C) relationship given by Eppley et al. (1970): $\log C(\mathrm{~g})=0.76 \log V(\mathrm{ml})-0.29$.

\section{RESULTS}

\section{Contribution of diatoms to total chl a}

Multiple linear regressions of the flume and in situ pigment data resulted in the following relationships: Flume (June 1997, Sites 1 to 4$)$ : chl $a=1.880+(0.718$ fuco $)-\left(0.59019^{\prime}\right.$-hexa $)+(0.274$ perid $) ; r=0.937, F=$ $117.5, \mathrm{n}=53, \mathrm{p}<0.0001$. Flume (September 1997, Sites $1,2$, and 4$): \operatorname{chl} a=1.320+(1.270 \mathrm{chl} b)+(0.913$ fuco $)+$ $\left(0.51119^{\prime}\right.$-hexa $)-(0.234$ perid $) ; \mathrm{r}=0.979, F=682.4, \mathrm{n}=$ 121, p $<0.0001$. In situ (late August 1996, Sites 2,4, and 5): chl $a=0.623+(1.550$ fuco $)-(0.89119 '$-hexa $)-$ $(0.133$ perid $) ; \mathrm{r}=0.956, F=232.2, \mathrm{n}=70, \mathrm{p}<0.0001$.

In all cases, fucoxanthin alone was able to predict chl a $(\mathrm{p}<0.0001)$. The relative contribution of diatoms to in situ total chl a in late August 1996 varied between $92.0 \pm 9.9 \%$ at Site 4 , and $94.4 \pm 6.9 \%$ at Site 2 . In the June 1997 flume experiments, diatoms accounted for between $74.1 \pm 11.8 \%$ (Site 1) and $99.2 \pm 28.8 \%$ (Site 3 ) of total chl $a$. In the September experiments, diatoms accounted for between $56.1 \pm 25.9 \%$ (Site 1) and $77.1 \pm$ $22.7 \%$ (Site 2) of total chl a. The chl a:fuco values derived from the flume experiments (0.91 in June, 0.72 in September) are rather low, and are probably caused by resuspension of detritus-rich sediments containing pigments with slower degradation rates relative to chl $a_{1}$ and so do not necessarily represent live biomass. Nevertheless, there was good agreement between diatom cell numbers and total chl $a$ in the flume when all the experiments were combined $(p<0.001)$. 


\section{Benthic-pelagic exchange of diatoms}

Diatom taxa identified and enumerated in situ (1996) and in the flume (1996 and 1997) are presented in Table 1. Both benthic and plankton/tychoplankton (hereafter referred to as plankton) species were present in all samples. In general, there was good agreement between flume and in situ communities. Exceptions included the chain-forming Rhizosolenia deliculata and the large centric diatom Coscinodiscus spp., both of which were more abundant in situ. Benthic forms such as Navicula spp., Nitzschia spp. and Rhaphoneis amphiceros were generally more abundant in the flume, because the enclosed system retained the cells resuspended from the sediment.

Field and experimental measures of diatom benthicpelagic exchange in June and August to September are presented using Site 2 as an example, with the remaining sites summarised in box-and-whisker plots and tables.

$$
\text { June-Site } 2
$$

Distinct peaks of in situ chl a and total diatom abundance and $\mathrm{C}$ occurred either side of the highwater slack period, particularly in the lower $35 \mathrm{~cm}$ of the water column (Fig. 1). These peaks were caused by resuspension of benthic diatoms, primarily of Navicula spp., Nitzschia spp., and Rhaphoneis amphiceros ( $\mathrm{p}<0.001)$, as well as the large centric diatom Coscinodiscus spp. $(\mathrm{p}<0.02)$. Navicula was the most abundant benthic genus (peak $180 \times 10^{3} \mathrm{l}^{-1}$ ). The epipsammic $R$. amphiceros was patchily distributed close to the seabed because of its tendency to occur in aggregations attached to sand grains, pieces of wood, and saltmarsh plant detritus. Although Coscinodiscus spp. were not as numerous as benthic diatoms (peak $70 \times 10^{3} \mathrm{l}^{-1}$ ), in terms of $\mathrm{C}$ this genus was clearly the most significant contributor to the observed spatial and temporal trends of biomass. It contributed $>90 \%$ to total diatom $\mathrm{C}$, and there was a significant correlation between its $\mathrm{C}$ biomass and total chl a $(\mathrm{p}<0.02)$.

Neither abundance nor C biomass of planktonic diatoms (excluding Coscinodiscus spp.) corresponded to total abundance or biomass ( $p>0.10)$. The chainforming Chaetoceros were rare in June, and found mainly near the bottom. Rhizosolenia deliculata and $R$. styliformis were distributed in the mid-water region during high-water slack, in densities of up to $200 \times 10^{3}$ $\mathrm{l}^{-1}$. Thalassionema nitzschoides was also distributed in this region, but with peak abundance occurring either side of high-water slack.

Table 1. Percentage contribution to mean 'live' cell abundance (no. $\mathrm{ml}^{-1}$ ) of numerically dominant diatom taxa observed in the flume and in situ measurements. Non-diatoms comprised of dinoflagellates, the chlorophyte Ankistrodesmis spp., euglenoids, and cyanobacteria. ${ }^{\mathrm{P}}$ : plankton/tychoplankton; ${ }^{\mathrm{B}}$ : benthic

\begin{tabular}{|c|c|c|c|c|c|c|}
\hline \multirow[t]{3}{*}{ Species } & \multicolumn{4}{|c|}{ Flume } & \multicolumn{2}{|c|}{ In situ } \\
\hline & Jun & Jun & Sep & Sep & Jun & Aug \\
\hline & 1996 & 1997 & 1996 & 1997 & 1996 & 1996 \\
\hline Non-diatoms & 14.8 & 6.4 & 3.0 & 1.1 & 29.3 & 7.9 \\
\hline \multicolumn{7}{|l|}{ Diatoms } \\
\hline Asterionella japonica $^{\mathrm{P}}$ & 0.6 & 2.7 & 4.6 & 14.8 & 2.0 & 3.7 \\
\hline 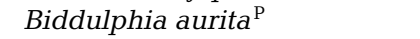 & 1.0 & 0.4 & 2.0 & 5.5 & 1.1 & 0.5 \\
\hline Chaetoceros spp. $(15 \mu \mathrm{m})^{\mathrm{P}}$ & 2.8 & 2.4 & 17.0 & 5.3 & 1.1 & 23.7 \\
\hline Chaetoceros spp. $(20 \mu \mathrm{m})^{\mathrm{P}}$ & 0.6 & 1.4 & 30.8 & 0.4 & 0 & 0.3 \\
\hline Coscinodiscus spp. ${ }^{\mathrm{P}}$ & 3.7 & 2.2 & 1.3 & 1.8 & 10.6 & 3.9 \\
\hline Leptocylindricus danicus $^{\mathrm{P}}$ & 0 & 0.1 & 2.9 & 0 & 0 & 1.9 \\
\hline Melosira spp. ${ }^{\mathrm{P}}$ & 0 & 6.2 & 0.9 & 2.1 & 0.3 & 0.9 \\
\hline Navicula spp. $(12 \mu \mathrm{m})^{\mathrm{B}}$ & 9.6 & 12.4 & 2.8 & 11.5 & 6.8 & 3.4 \\
\hline Navicula spp. $(25 \mu \mathrm{m})^{\mathrm{B}}$ & 21.3 & 17.9 & 2.4 & 16.6 & 5.3 & 2.8 \\
\hline Navicula spp. $(38 \mu \mathrm{m})^{\mathrm{B}}$ & 5.5 & 0.4 & 0.2 & 0.4 & 0.2 & 0.2 \\
\hline Nitzschia closterium $^{\mathrm{P}}$ & 7.0 & 5.3 & 3.5 & 4.9 & 1.3 & 4.6 \\
\hline Nitzschia seriata $^{\mathrm{P}}$ & 2.8 & 3.4 & 2.2 & 0.6 & 0.5 & 1.8 \\
\hline Nitzschia spp. $(12 \mu \mathrm{m})^{\mathrm{B}}$ & 3.3 & 6.0 & 3.4 & 1.8 & 2.0 & 3.4 \\
\hline Nitzschia spp. $(25 \mu \mathrm{m})^{\mathrm{B}}$ & 1.7 & 4.5 & 0.9 & 2.1 & 0.8 & 1.0 \\
\hline Rhaphoneis amphiceros $^{\mathrm{B}}$ & 3.6 & 7.8 & 0.7 & 8.2 & 3.1 & 1.0 \\
\hline Rhizosolenia deliculata $^{\mathrm{P}}$ & 5.6 & 0.2 & 3.7 & 0.3 & 19.0 & 11.1 \\
\hline Rhizosolenia styliformis $^{\mathrm{P}}$ & 4.6 & 1.1 & 0.4 & 0 & 4.8 & 0.3 \\
\hline Thalassionema nitzschoides ${ }^{\mathrm{P}}$ & 2.9 & 5.9 & 1.0 & 2.2 & 7.3 & 5.4 \\
\hline Thalassiosira spp. ${ }^{\mathrm{B}}$ & 0.9 & 2.5 & 11.2 & 0 & 0.2 & 1.4 \\
\hline Others ${ }^{\mathrm{P}+\mathrm{B}}$ & 7.7 & 10.8 & 5.1 & 20.4 & 5.5 & 9.9 \\
\hline
\end{tabular}



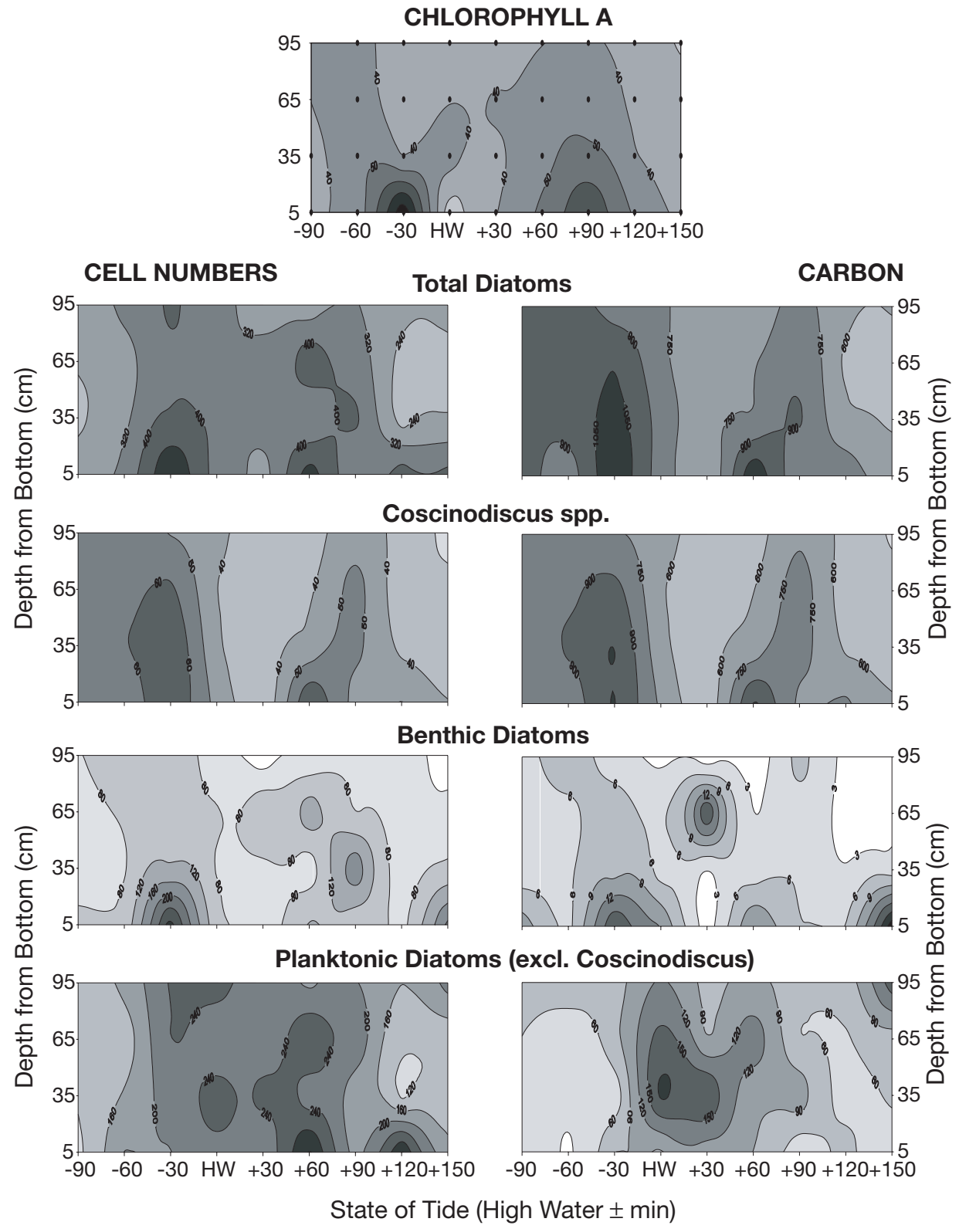

Fig. 1. In situ profiles of $\mathrm{chl}$ a $\left(\mathrm{mg} \mathrm{m}^{-3}\right)$, and Coscinodiscus spp., total, benthic, and remaining planktonic diatom abundance (no. $\times 10^{3} \mathrm{l}^{-1}$ ) and carbon $\left(\mathrm{mg} \mathrm{m}^{-3}\right)$ in a $95 \mathrm{~cm}$ water column over Site 2 of the Molenplaat in June 1996

The principal trends observed in the field measurements were confirmed in the flume experiments carried out using sediments from Site 2 in June (Fig. 2). Large increases in the number of benthic diatoms occurred above $25 \mathrm{~cm} \mathrm{~s}^{-1}$, following the stripping of the algal mat from the sediment surface. By $30 \mathrm{~cm} \mathrm{~s}^{-1}$ the contribution of benthic species to total diatom abundance in the water was $70 \%$, equivalent to only $\sim 10 \%$ in terms of C. As with the in situ observations, low benthic $\mathrm{C}$ was caused by the presence of Coscinodiscus spp. at higher current velocities. Following the erosion experiments, the flume was occasionally switched down to $5 \mathrm{~cm} \mathrm{~s}^{-1}$ to observe deposition. Sinking of microalgae was extremely rapid, as particles were stripped out of the water column by larger sand grains; the Lugol-preserved water samples often contained only a few small diatoms and detritus particles.

\section{August to September-Site 2}

In late August-early September, in situ peaks of chl a biomass either side of the high-water slack period 

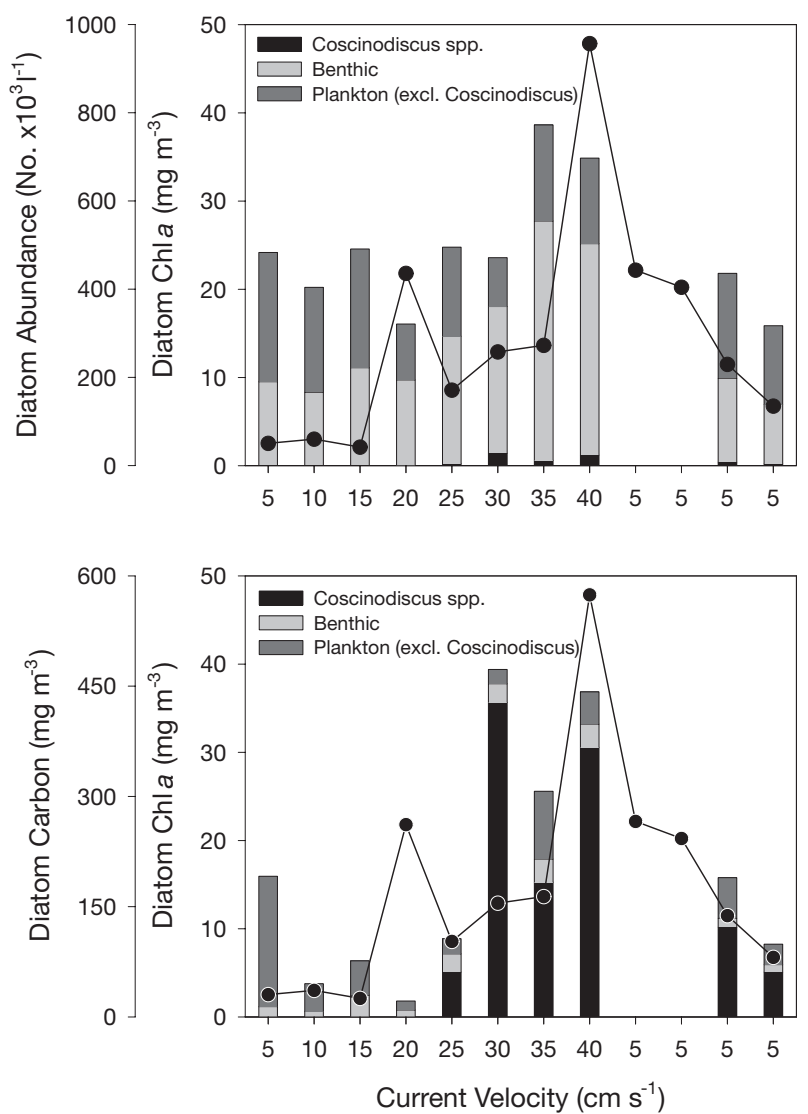

Fig. 2. Flume observations of changes in Coscinodiscus spp., benthic, and remaining planktonic diatom abundance and carbon biomass in response to a stepwise increase in current velocity from 5 to $40 \mathrm{~cm} \mathrm{~s}^{-1}$ followed by a reduction to $5 \mathrm{~cm} \mathrm{~s}^{-1}$, using sediment from Site 2 in June 1997

were still evident. However, diatom cells were more patchily distributed compared with June, and many appeared to be more numerous in the mid-upper regions of the water column (Fig. 3). The lack of correlation ( $p>0.10$ ) between total chl $a$ and either Coscinodiscus spp., total or benthic diatom abundance and biomass may have been caused by reduced microphytobenthos available for resuspension, coupled with the general reduction in diatom abundance and species diversity. Thus, it was more difficult to distinguish between local resuspension and advective processes. The total chl a may also represent non-diatom algae (although the contribution of diatoms was estimated to be $>90 \%$ ), or detrital chl a not indicative of 'live' biomass. In the September flume experiments, clear trends also tended to be more difficult to identify. However, at Site 2 the sharp increase in diatom biomass at $30 \mathrm{~cm} \mathrm{~s}^{-1}$ was clearly the result of resuspension of Coscinodiscus spp. (Fig. 4).

\section{June and August-September-all sites}

The relative contributions of benthic diatoms and Coscinodiscus spp. to in situ total diatom abundance and $\mathrm{C}$ in the water column at each site are summarised in Figs. 5 \& 6 respectively.

In terms of total cell abundance, benthic diatoms accounted for, on average, between 15.3 and $42.2 \%$ in June, and between 22.5 and $25.6 \%$ in late August. At $5 \mathrm{~cm}$ above the seabed, contributions were only 2 to $6 \%$ more. The greatest contribution of benthic diatoms was found at the siltiest site (Site 2), which had the most microphytobenthos biomass in the surface sediment available for resuspension. The lowest contribution was at the sandiest site (Site 5) located at the edge of the Molenplaat. However, variability in the contribution of benthic diatoms over the flood-ebb period was generally greatest at the more erodable sandier sites. Spring and autumn measurements at Sites 2 and 4 revealed that a slightly higher proportion of the water-column population was composed of benthic species.

In terms of total diatom $\mathrm{C}$, the contribution of benthic diatoms was extremely low in June, $<1.4 \%$. Although microphytobenthos biomass was much lower in September, particularly at Site 2 , the contribution of benthic species to water-column biomass was considerably higher. Key planktonic genera such as Coscinodiscus spp. and Rhizosolenia spp. were present in much lower numbers, resulting in a much lower overall diatom $\mathrm{C}$ biomass. It should be noted, however, that the mean and median values at Site 2 were very different from each other $(2.1 \%$ and $14.3 \%)$, and the distribution was skewed towards higher values. The occasional presence of large benthic genera such as Pleurosigma and Gyrosigma spp., in densities of up to $18 \times 10^{3} \mathrm{l}^{-1}$ biased the mean value. Site 4 , which did not have the same pronounced seasonal peak in microphytobenthos biomass as Site 2, had similar water-column contributions by benthic diatoms in June (mean $0.9 \%$ ) and September (mean $2.5 \%$ ).

The relative contributions of benthic diatoms and Coscinodiscus spp. to total diatom abundance and $\mathrm{C}$ at selected current velocities in the flume are summarised in Table 2 (1996) and Table 3 (1997). Numerically, the relative contribution of benthic species was slightly higher in 1997 compared with 1996 ( $p$ < 0.05), primarily because of low abundance in September 1996. On a C basis, however, there was a significantly greater contribution by benthic species in 1997 ( $p<0.001)$. Average values at $25 \mathrm{~cm} \mathrm{~s}^{-1}$ were $35.8 \%$ in 1997 compared with $3.6 \%$ in 1996. This was caused by an increase in the number of larger planktonic species in 1996, which thereby reduced the relative contribution of smaller benthic species, and to a lesser extent because of greater resuspension of benthic species in 1997. The sediment in June 


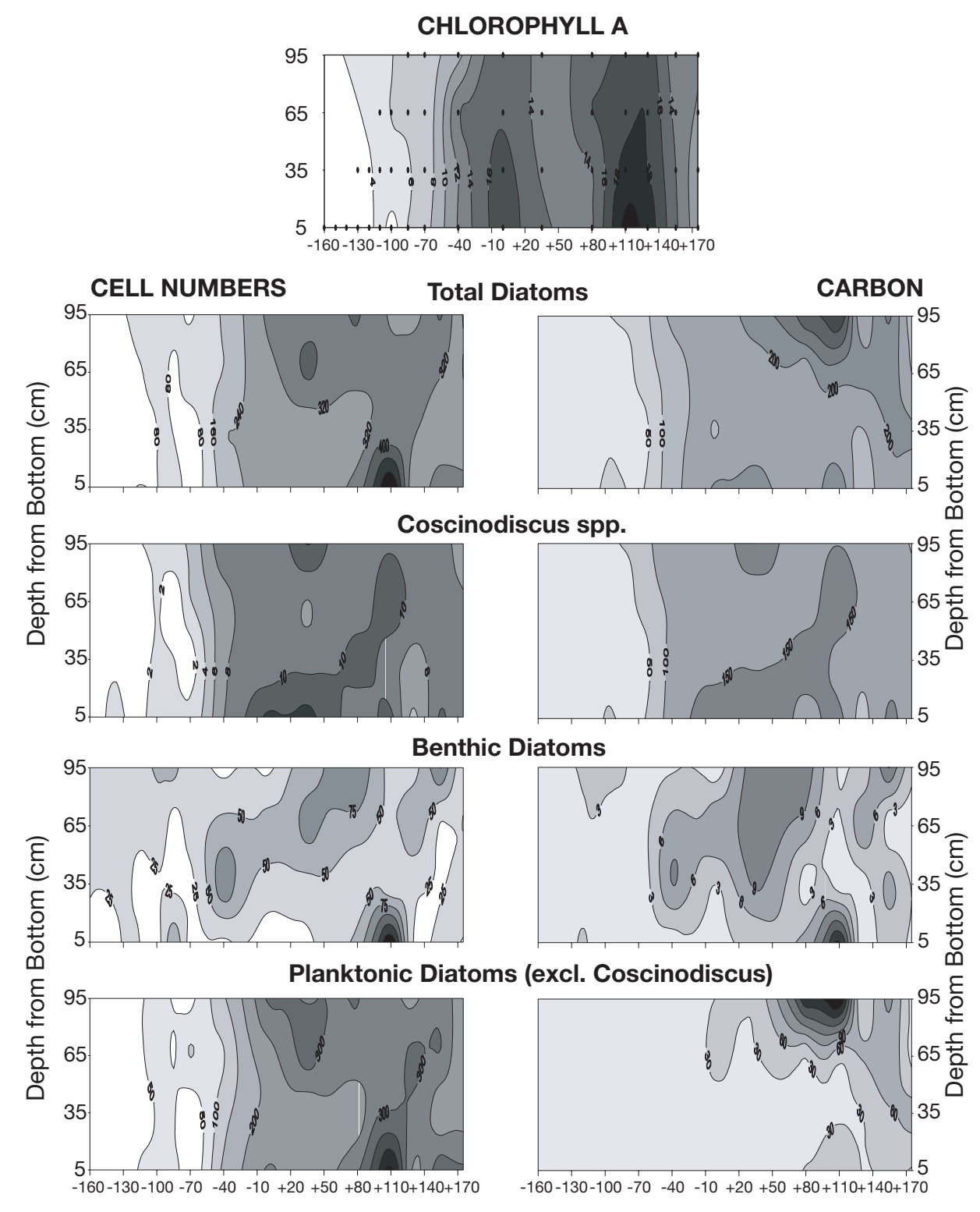

State of Tide (High Water \pm min)

Fig. 3. In situ profiles of chl a $\left(\mathrm{mg} \mathrm{m}^{-3}\right)$, and Coscinodiscus spp., total, benthic, and remaining planktonic diatom abundance $\left(\right.$ no. $\left.\times 10^{3} \mathrm{l}^{-1}\right)$ and carbon $\left(\mathrm{mg} \mathrm{m}^{-3}\right)$ in a $95 \mathrm{~cm}$ water column over Site 2 of the Molenplaat in late August 1996

1997 was more erodable than in June 1996 because of reduced microphytobenthos biomass and increased destabilisation by the clam Macoma balthica.

\section{Tidal simulation}

In June 1997, a tidal simulation experiment was carried out in the flume using sediment from Site 4 . Several diatoms, both benthic and planktonic, displayed cycles of abundance closely related to the changes in current velocity ( $\mathrm{p}<0.05)$ (Fig. 7). The planktonic diatoms Coscinodiscus spp., and to a lesser extent Thalassiosira, As- terionella, Lithodesmium and Pinnularia, displayed similar trends to those of the benthic genera Navicula and Nitzschia, implying that they sank to the sediment at low current velocities. Overall, abundance of benthic diatoms was much greater, and at the high current velocities $\left(40 \mathrm{~cm} \mathrm{~s}^{-1}\right)$, they showed a 10 -fold increase in abundance as the underlying sediment underwent bedload transport to several centimetres depth. Nevertheless, their contribution to total diatom biomass was less significant because of the presence of Coscinodiscus spp. (Fig. 8). Nitzschia closterium abundance was unnaturally high at $T_{0}$ because it was cultured during ${ }^{15} \mathrm{~N}$-labelling of the seawater that was added to the flume (see Herman et 

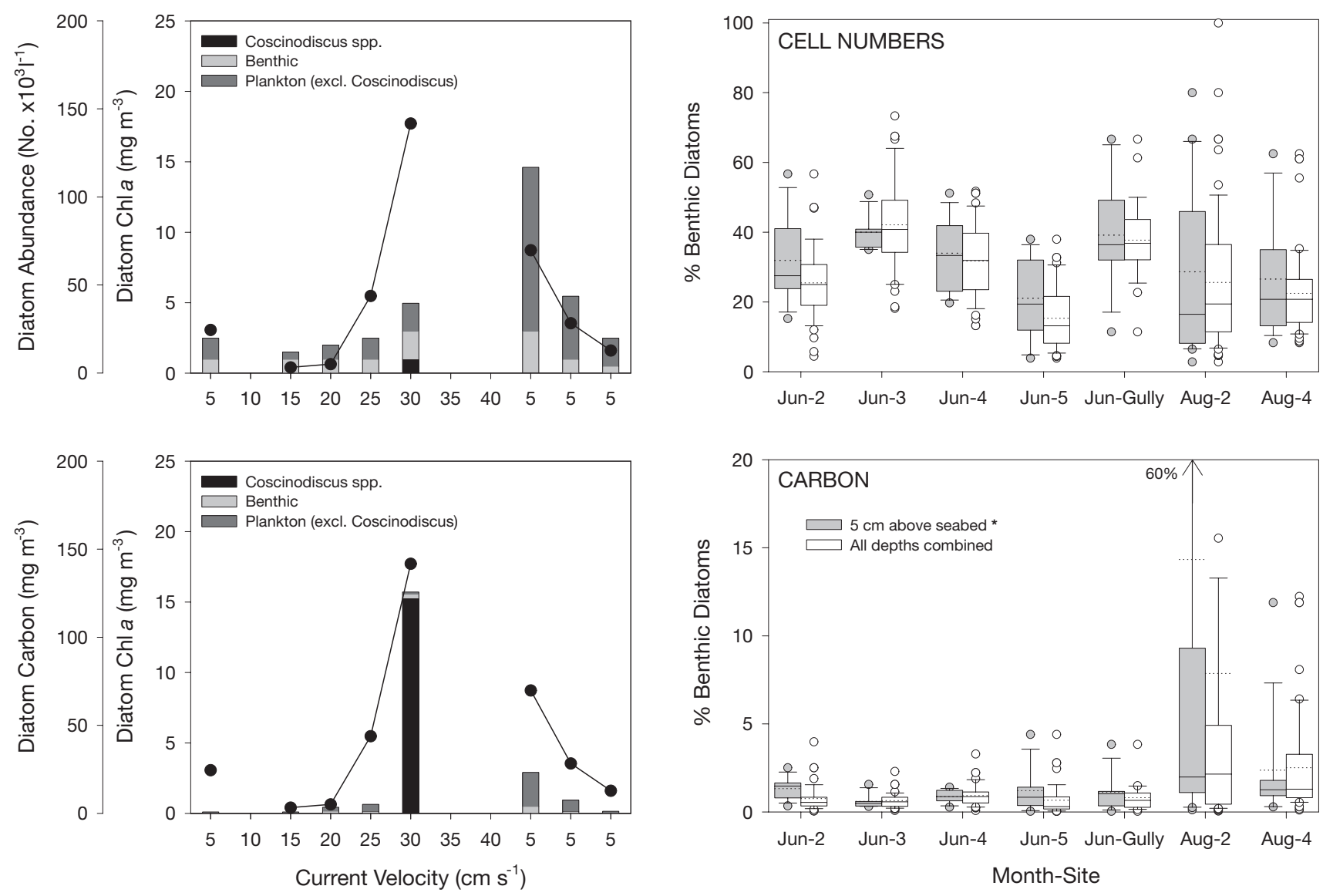

Fig. 4. Flume observations of changes in Coscinodiscus spp., benthic, and remaining planktonic diatom abundance and carbon biomass in response to a stepwise increase in current velocity from 5 to $40 \mathrm{~cm} \mathrm{~s}^{-1}$ followed by a reduction to $5 \mathrm{~cm} \mathrm{~s}^{-1}$, using sediment from Site 2 in September 1997

Fig. 5. Box-and-whisker plots summarising contribution of benthic diatoms to in situ total diatom abundance and carbon at $5 \mathrm{~cm}$ and 5 to $95 \mathrm{~cm}$ (combined) depths above the seabed. Boxes represent 25th and 75th percentiles; whiskers represent 10th and 90th percentiles; median (continuous line), mean (dotted line), and outliers (symbols) are also shown. *: gully is variable depth

Table 2. Summary of change in relative contribution of benthic diatoms and Coscinodiscus spp. to total diatom abundance (no. $\times 10^{3} \mathrm{l}^{-1}$ ) and carbon $\left(\mu \mathrm{g} \mathrm{1}^{-1}\right.$ ) in the 1996 flume experiments, at current velocities of 5, 15, 20 (September or $30 \mathrm{June}$ ) $\mathrm{cm} \mathrm{s}^{-1}$. nd: no data

\begin{tabular}{|c|c|c|c|c|c|c|c|c|c|c|c|c|}
\hline \multirow[t]{3}{*}{ Site } & \multicolumn{6}{|c|}{ Benthic diatoms } & \multicolumn{6}{|c|}{ Coscinodiscus spp. } \\
\hline & \multicolumn{3}{|c|}{$\%$ abundance } & \multicolumn{3}{|c|}{ \% carbon } & \multicolumn{3}{|c|}{$\%$ abundance } & \multicolumn{3}{|c|}{ \% carbon } \\
\hline & 5 & 15 & $20 / 30$ & 5 & 15 & $20 / 30$ & 5 & 15 & $20 / 30$ & 5 & 15 & $20 / 30$ \\
\hline \multicolumn{13}{|l|}{ June } \\
\hline 1 & 49.9 & 78.4 & 61.7 & 4.2 & 7.5 & 9.5 & 2.9 & 2.9 & 4.8 & 74.5 & 84.0 & 79.7 \\
\hline 2 & 45.8 & 65.8 & 65.3 & 1.0 & 5.1 & 6.9 & 17.3 & 3.5 & 3.4 & 91.7 & 80.1 & 73.6 \\
\hline 3 & 35.5 & 27.4 & 56.7 & 2.2 & 1.8 & 10.3 & 7.7 & 6.9 & 3.8 & 83.1 & 88.2 & 78.7 \\
\hline 5 & 16.3 & 31.3 & 65.2 & 0.1 & 3.2 & 3.2 & 57.3 & 37.7 & 10.9 & 96.9 & 98.0 & 92.9 \\
\hline \multicolumn{13}{|c|}{ September } \\
\hline 1 & 9.3 & nd & 11.0 & 0.6 & nd & 1.4 & 2.1 & nd & 3.5 & 55.0 & nd & 66.7 \\
\hline 2 & 16.0 & nd & 20.5 & 1.0 & nd & 2.2 & 2.5 & nd & 1.2 & 66.6 & nd & 68.1 \\
\hline 3 & 21.0 & nd & 29.3 & 2.2 & nd & 2.2 & 1.6 & nd & 4.9 & 50.8 & nd & 67.8 \\
\hline 5 & 9.1 & nd & 12.7 & 3.1 & nd & 2.0 & 0.1 & nd & 87.0 & 7.8 & nd & 41.8 \\
\hline
\end{tabular}



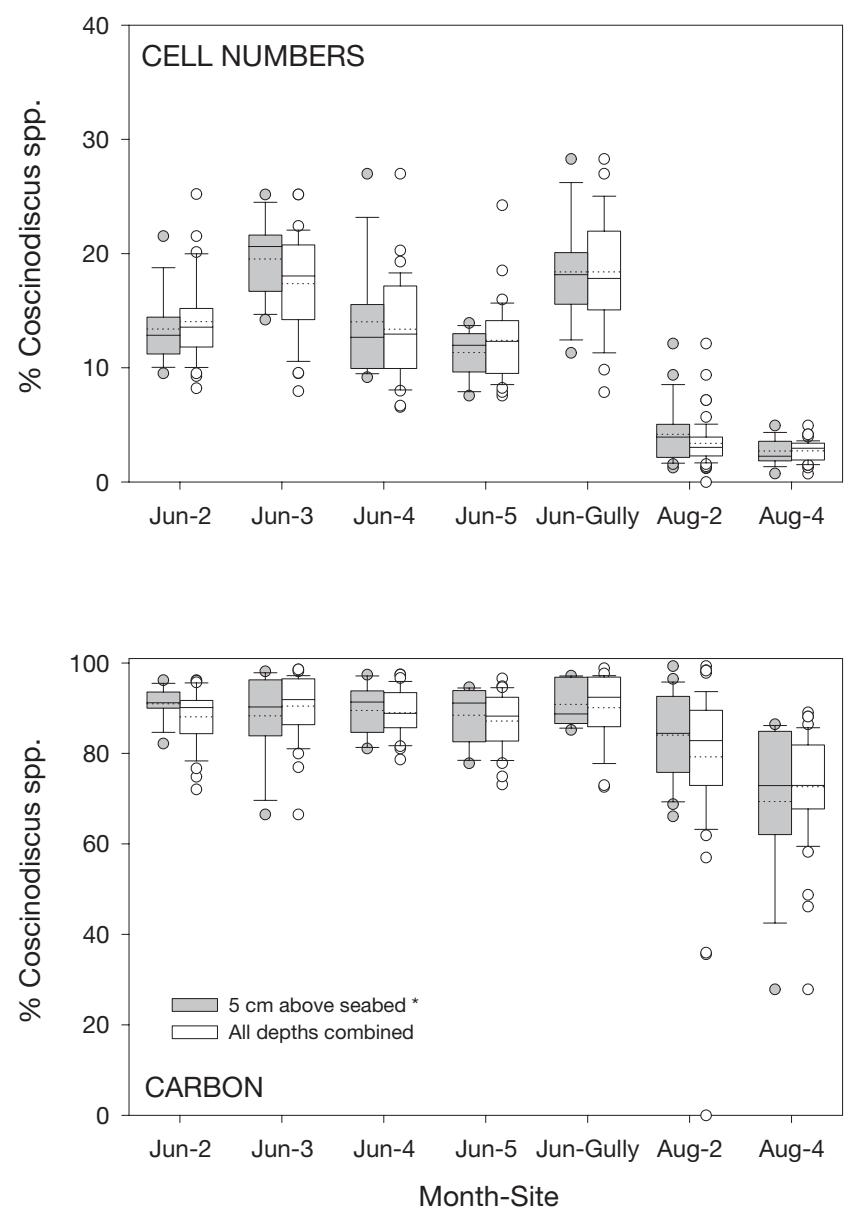

Fig. 6. Box-and-whisker plots summarising contribution of Coscinodiscus spp. to in situ total diatom abundance and carbon at $5 \mathrm{~cm}$ and 5 to $95 \mathrm{~cm}$ (combined) depths above the seabed. Box represents 25th and 75th percentiles; whiskers represent 10th and 90th percentiles; median (continuous line), mean (dotted line), and outliers (symbols) are also shown. ${ }^{*}$ : gully is variable depth al. 2000). Its rapid decline was caused by benthic suspension-feeding activity.

\section{The role of diatom frustules}

Diatom frustules (i.e., dead diatom cells) were enumerated in both the flume and in situ water samples. Because frustules tend to settle and accumulate on the seabed, they provided excellent indicators of resuspension events in situ. A vertical profile of frustules at Site 2 (Fig. 9) was very similar to those of suspended particulate matter (SPM) presented in Lucas et al. (2000). Although live and dead cells are resuspended from sediments, the number of frustules increased relative to live cells at high current velocities, thereby reducing the quality of organic material. In the flume experiments, the percentage of live diatom cells decreased from $55-70 \%$ at $5 \mathrm{~cm} \mathrm{~s}^{-1}$ to $5-35 \%$ at $30 \mathrm{~cm} \mathrm{~s}^{-1}$ (Fig. 10), with the proportion of live cells greatest at sandy sites and in June. Overall, the range of values is similar in the flume and in situ. Spatially, the flume trends are in broad agreement with the in situ measurements, where the percentage of live diatoms in June was lowest at Site 2 (52.0\% at $5 \mathrm{~cm}$ above the seabed) and highest at Sites 1,4 and 5 (60.2 to $68.0 \%$ at $5 \mathrm{~cm}$ above the seabed) (Fig. 11). Temporally, however, the in situ September values are slightly higher than those in June.

\section{DISCUSSION}

\section{Water-column perspective}

Inter-site, seasonal, and inter-annual differences in water-column chl a appeared to be influenced by the

Table 3. Summary of change in relative contribution of benthic diatoms and Coscinodiscus spp. to total diatom abundance (no. $\times$ $10^{3} \mathrm{l}^{-1}$ ) and carbon ( $\mu \mathrm{g} \mathrm{l}^{-1}$ ) in the 1997 flume experiments, at current velocities of 5, 15, and $30 \mathrm{~cm} \mathrm{~s}^{-1} .2^{*}$ : cockle-enhanced experiment; nd: no data

\begin{tabular}{|c|c|c|c|c|c|c|c|c|c|c|c|c|}
\hline \multirow[t]{3}{*}{ Site } & \multicolumn{6}{|c|}{ Benthic diatoms } & \multicolumn{6}{|c|}{ Coscinodiscus spp. } \\
\hline & \multicolumn{3}{|c|}{$\%$ abundance } & \multicolumn{3}{|c|}{$\%$ carbon } & \multicolumn{3}{|c|}{$\%$ abundance } & \multicolumn{3}{|c|}{ \% carbon } \\
\hline & 5 & 15 & $20 / 30$ & 5 & 15 & $20 / 30$ & 5 & 15 & $20 / 30$ & 5 & 15 & $20 / 30$ \\
\hline \multicolumn{13}{|c|}{ June } \\
\hline 1 & 34.4 & 29.4 & 65.9 & 8.2 & 8.9 & 61.0 & 0 & 1.1 & 0 & 0 & 49.6 & 0 \\
\hline 2 & 33.9 & 32.6 & 70.2 & 13.9 & 21.7 & 9.7 & 2.0 & 0 & 4.0 & 30.8 & 0 & 83.6 \\
\hline 3 & 22.9 & 39.8 & 70.3 & 8.5 & 6.2 & 1.6 & 0 & 3.2 & 27.0 & 0 & 38.3 & 98.3 \\
\hline 4 & 35.1 & 50.0 & 50.7 & 10.8 & 18.4 & 10.6 & 1.4 & 2.3 & 3.7 & 41.6 & 73.6 & 76.3 \\
\hline \multicolumn{13}{|c|}{ September } \\
\hline 1 & 28.8 & 17.5 & 33.3 & 15.8 & 1.9 & 1.4 & 3.5 & 1.6 & 22.2 & 46.5 & 42.2 & 78.1 \\
\hline 2 & 27.2 & 61.9 & 63.0 & 13.0 & 12.0 & 44.1 & 0 & 0 & 10.0 & 0 & 0 & 49.1 \\
\hline $2^{*}$ & 33.3 & 50.0 & nd & 14.9 & 31.3 & nd & 0 & 0 & nd & 0 & 0 & nd \\
\hline 5 & 39.1 & nd & 68.4 & 37.7 & nd & 79.0 & 0 & nd & 0 & 0 & nd & 0 \\
\hline
\end{tabular}



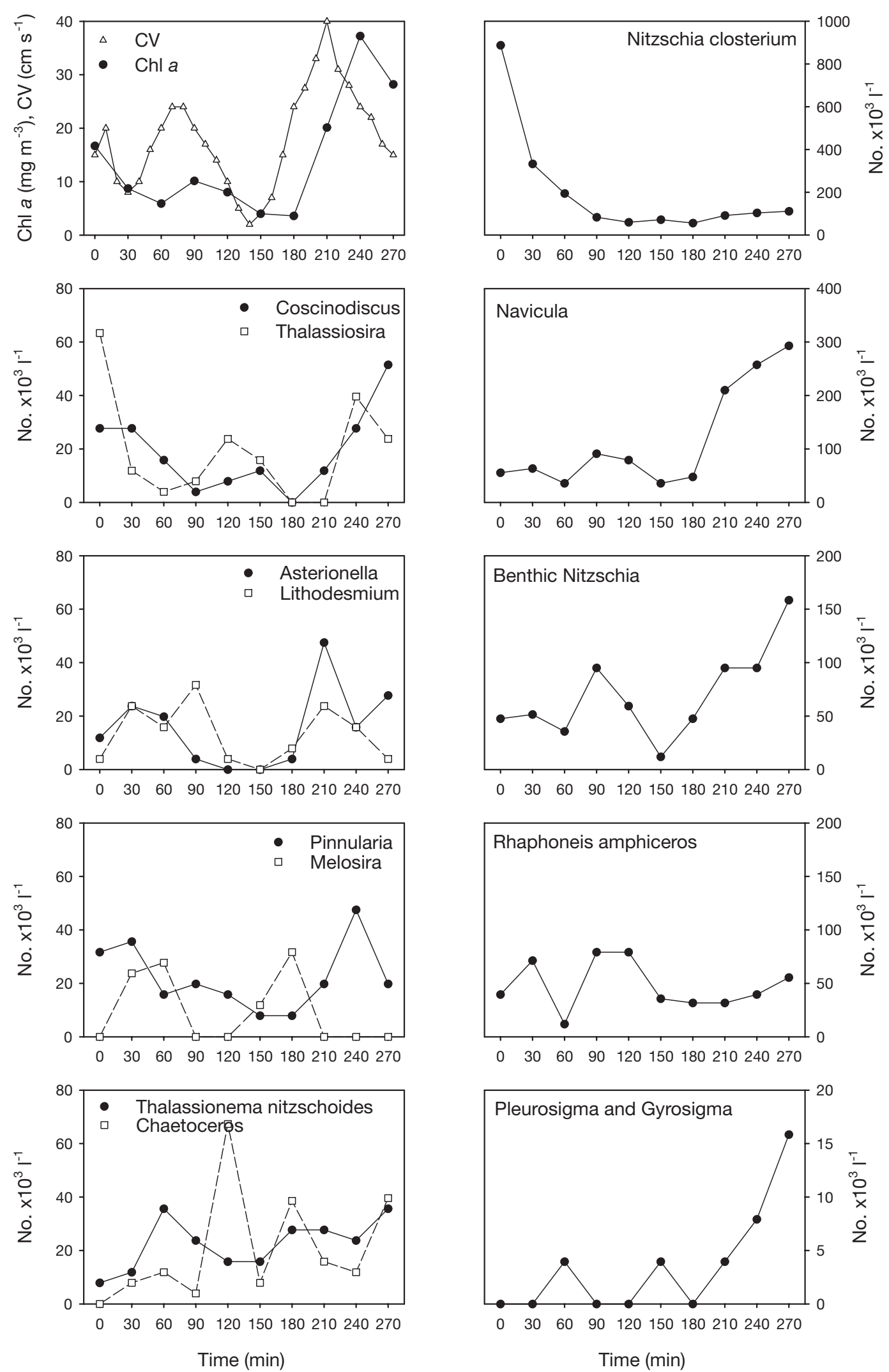

Fig. 7. Changes in abundance of most common diatom taxa during a flume experiment simulating in situ changes in current velocity (CV) in June 1997, using sediment from Site 4 

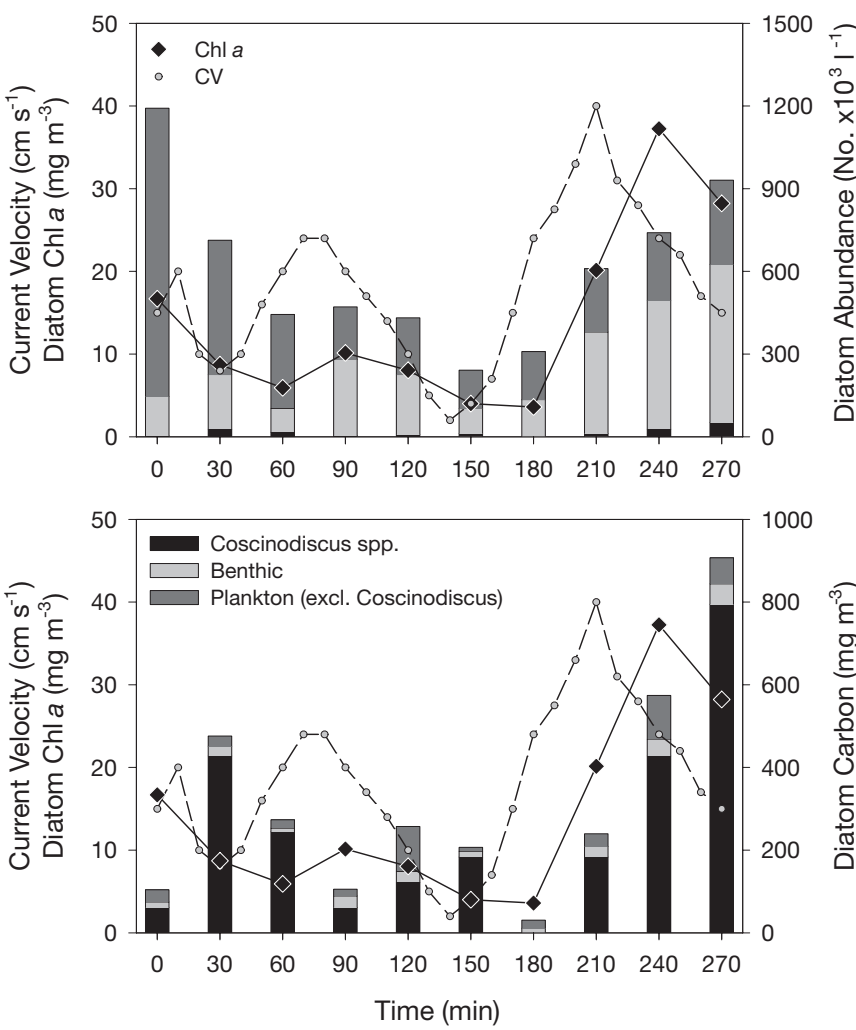

Fig. 8. Summary of changes in abundance and carbon biomass of Coscinodiscus spp., benthic, and remaining planktonic diatoms during a flume experiment simulating in situ changes in current velocity (CV) in June 1997, using sediment from Site 4

balance between phytoplankton and microphytobenthos biomass and community composition. The presence of benthic microalgae as temporary members of the plankton is influenced by the feedback between biomass available for resuspension, and its stabilising influence on the surrounding sediment via the production of extracellular polymeric substances (EPS) (Lucas et al. 2000). Values of $U_{\text {crit }}$ (i.e., the critical erosion velocity required to increase SPM above a threshold of $100 \mathrm{mg} \mathrm{l}^{-1}$ ) obtained from the flume experiments in 1997 ranged between 20.4 and $23.0 \mathrm{~cm} \mathrm{~s}^{-1}$ in June, when microphytobenthos biomass was high, and between 13.6 and $19.3 \mathrm{~cm} \mathrm{~s}^{-1}$ in September, when microphytobenthos biomass was low (Lucas \& Holligan 1999, Lucas et al. 2000). The overall contribution of benthic species was slightly higher in sandy sediments and in the autumn because of increased erodability of these sediments.

The majority of microphytobenthos resuspension studies have based their estimates of the relative contribution of benthic species to the plankton either on changes in total chl a or on cell numbers, without relating abundance to biomass. The importance of coupling

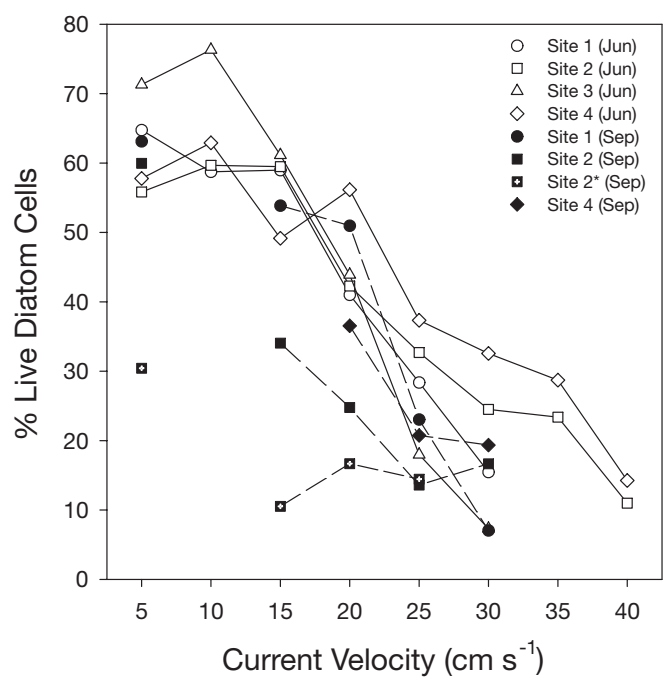

Fig. 10. Change in percentage of live diatoms measured in response to a stepwise increase in current velocity in the flume, using sediments from Sites 1,2 3, and 4 in June and September 1997. ${ }^{*}$ : cockle-enhanced experiment

taxonomic identification and enumeration with estimates of chl a or C biomass has been highlighted in this study, as the 2 measures resulted in very different estimates of the relative contribution of suspended benthic diatoms. This is because resuspension of several planktonic species at high current velocities, combined with the very large differences in cell volume between smaller benthic (pennate) diatoms and larger planktonic (centric and some pennate) diatoms, greatly influenced cell to $\mathrm{C}$ conversions. In spite of the fact that benthic diatoms were often more numerous than planktonic ones, their contribution to total diatom $\mathrm{C}$ was often $<5 \%$.

Combined flume and in situ measurements of resuspension of sediment and associated (benthic) chl a from the Molenplaat tidal flat have been described in earlier papers (Lucas et al. 2000, Widdows et al. 2000).

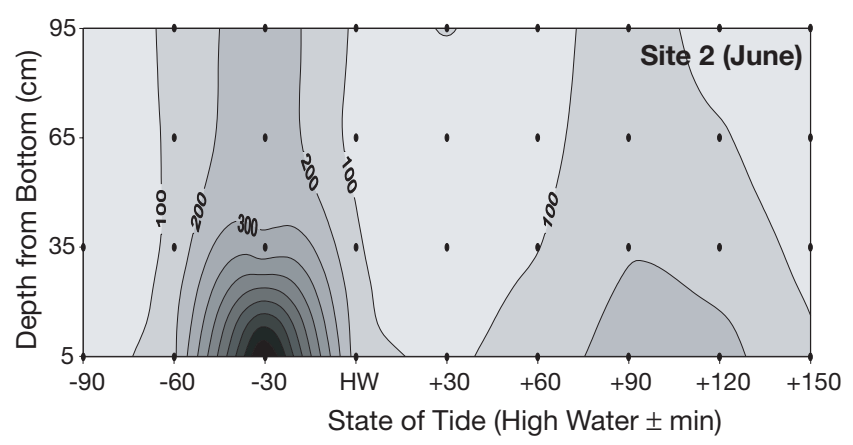

Fig. 9. In situ profile of diatom frustules in a $95 \mathrm{~cm}$ water column above Site 2 in June 1996 


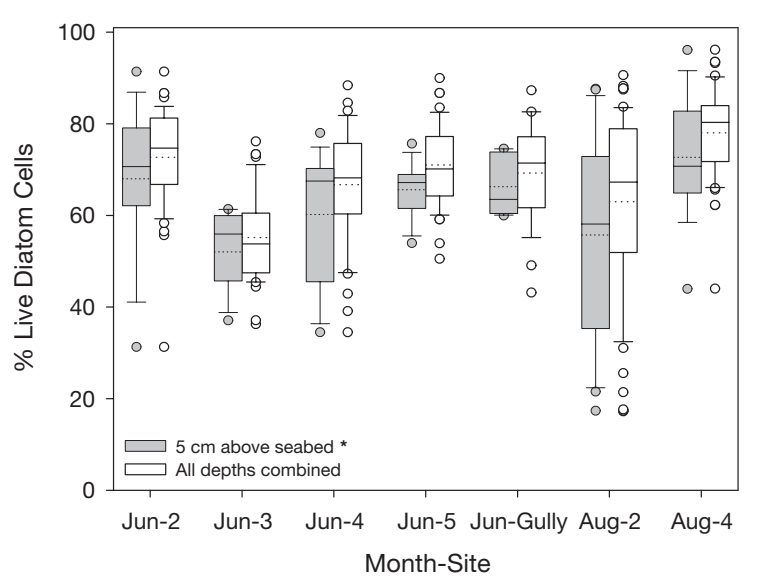

Fig. 11. Box-and-whisker plots summarising contribution of live diatoms to in situ total diatom abundance at $5 \mathrm{~cm}$ and 5 to $95 \mathrm{~cm}$ (combined) depths above the seabed. Boxes represent 25th and 75th percentiles; whiskers represent 10th and 90th percentiles; median (continuous line), mean (dotted line), and outliers (symbols) are also shown. * gully is variable depth

The present study clearly demonstrated that much of the small-scale temporal and spatial variability in chl a biomass observed in the water column was caused by resuspension and deposition of the large planktonic diatom Coscinodiscus spp., as well as benthic diatoms. (It should be noted that advective processes have not been considered.) Although detailed studies of this phenomenon are virtually absent, similar findings have been reported by Roman \& Tenore (1978). These authors observed that chl a peaks in Buzzards Bay were characterised by the presence of large numbers of resuspended benthic diatoms (e.g., Pleurosigma spp., Gyrosigma spp., Nitzschia spp.), but then went on to say that resuspension of chl a represents both endemic benthic diatoms and the reintroduction of phytoplankton cells that have sunk out of the water column. Graf \& Rosenberg (1997) have also stated that the near-bottom water in estuaries is not only affected by fluxes up from the sediment, but also from settling material from the water column.

Sinking of organic particles represents a major loss of organic matter out of the water column. Evidence that sinking occurs is well known, although much of the evidence comes from stratified, open-water environments (Kiørboe 1993) where turbulent currents are weak and the risk of sinking out of the euphotic zone is high. Eppley et al. (1967), Smayda (1970), and Sournia (1982) have summarised the mechanisms aiding suspension/flotation of phytoplankton in the sea as morphological (cell shape, size, colony formation, protuberances), physiological (lipid reserves, ionic regulation) and physical. For non-motile phytoplankton such as diatoms, the distribution of cells is closely coupled with physical mixing processes. Nevertheless, their form and behaviour are complex, with several interactions between morphology and physiology apparent (Estrada \& Berdalet 1997). Intuitively, large diatoms sink faster than small ones, although at proportionally slower rates (Smayda 1970). Thus, in the relatively shallow water over the tidal flats in the Westerschelde, the large cells $(\sim 200 \mu \mathrm{m})$ of Coscinodiscus spp. sink rapidly to the seabed during slack periods in the tidal cycle. Similarly, colonies of cells (e.g., Chaetoceros spp., Thalassionema nitzschoides, Asterionella japonica) sink faster than single cells (Eppley et al. 1967). Sinking rates of these diatoms may be increased via biodeposition (Graf \& Rosenberg 1997), and/or the rapid sinking of relatively large, heavy sand grains. The stripping of the water column in this way has been reported by Lucas et al. (2000).

The distribution of phytoplankton populations relative to the euphotic zone of turbid estuaries has important implications for the overall metabolism of the estuary. Van Spaendonk et al. (1993) reported that high nutrient concentrations year-round and very high turbidity in the well-mixed Westerschelde estuary results in light-limited phytoplankton growth. Because the ratio of the euphotic zone to mixing zone $\left(Z_{\mathrm{eu}}: Z_{\mathrm{m}}\right)$ is low ( 0.1 to 0.3 at Hansweert, located in the vicinity of the Molenplaat), algae could spend much of their time in darkness, resulting in low photosynthesis and high respiratory losses. Net pelagic photosynthetic production is relatively low in the Westerschelde (Kromkamp et al. 1995). Nevertheless, van Spaendonk et al. (1993) report unexpected biomass increases because the algae are shade-adapted, resulting in lower respiratory loss and higher light utilisation efficiency. MacIntyre \& Cullen (1996) report that resuspended benthic microalgae have high rates of production due to high chlorophyll-specific light-saturated rates of photosynthesis. In addition, the algae are continuously mixed throughout the water column, which enhances their efficiency of nutrient uptake (Munk \& Riley 1952).

\section{Benthic perspective}

In addition to the effects of resuspension and deposition on water-column productivity and biomass, the findings presented herein have important implications for the nutritional ecology of benthic macrofauna that rely on advective processes for their microalgae supply. From stable-isotope labelling experiments, Herman et al. (2000) have recently determined the relative importance of microphytobenthos- and phytoplankton- derived food for benthic macrofauna on the Molenplaat. Their main conclusion was that, in spite of resuspension of microphytobenthos at high current 
velocities, infaunal suspension feeders (e.g., Cerastoderma edule and Mya arenaria) showed feeding preferences towards pelagic algae. Benthic grazers (e.g., Hydrobia ulvae and Bathyporeia sp.) had a $\delta^{13} \mathrm{C}$ close to that of benthic algae, and a number of deposit feeders had intermediate $\delta^{13} \mathrm{C}$ values.

The utilisation of planktonic algae by benthic suspension feeders has been reported for Macoma balthica (Hummel 1985), but not for Mytilus edulis (Muschenheim \& Newell 1992). Ontogenetic shifts in food preference from small microphytobenthos in juveniles to large plankton in adults, have been reported for M. balthica (Herman et al. 2000) and Cerastoderma edule (Kang et al. 1999). The present study indicates that the planktonic diatoms may be made available to benthic suspension feeders during deposition from the water column as well as resuspension from the seabed. Their large size relative to benthic species would provide a source of organic-rich food, although this would be tempered by high SPM loads during resuspension events (Lucas et al. 2000).

The second benthic issue concerns the potential role of Coscinodiscus spp. as a temporary member of the benthos. In other words, could Coscinodiscus spp. be considered as tychoplanktonic in this environment? In the flume experiments, it was noticed that Coscinodiscus spp. were present at $T_{0}$ in 1996, but absent at $T_{0}$ in 1997. The reason for this is unclear, but may simply reflect differences in abundance that were observed between the 2 years. What is clear, however, is that there were real increases in Coscinodiscus spp. abundance with increasing current velocity in the flume, and that the sediment must have been the source. The in situ water profiles also provided compelling evidence that at least some of the Coscinodiscus spp. were resuspended from the sediment. Although phytoplankton cells were very rarely found in the sediments, it has been demonstrated that few are required to make a significant contribution to biomass.

\section{Conclusions}

The combined flume and in situ measurements of diatom resuspension and deposition have identified that: (1) Increased current velocities result in an increase in the number of benthic and pelagic diatoms in the water column. (2) When current velocities are high, the contribution of resuspended benthic diatoms to the water-column population is considerable in terms of numerical abundance (up to $70 \%$ in June). In terms of carbon biomass, however, this equates to $<5 \%$. (3) A greater proportion of diatom abundance is composed of benthic species in areas above sandy sediments and in the autumn, because of increased erodability of the underlying microphytobenthos mat. (4) The large planktonic diatom Coscinodiscus spp. sinks when currents are weak, and becomes resuspended when currents increase. It is the most significant contributor to total diatom biomass ( $90 \%$ in June and 60 to $80 \%$ in September), and is the cause of smallscale and short-term changes in diatom biomass. (5) Diatom frustules are a useful indicator of resuspension.

Acknowledgements. Many thanks go to Peter Herman, Jack Middelburg, Adri Sandee, Pieter van Rijswijk and Bernard Krebs for carrying out the in situ seston sampling in difficult conditions, and subsequent SPM analysis. John Widdows, Mary Brinsley, Pete Salkeld, and Colin Barrett from the Plymouth Marine Laboratory (PML) made significant contributions to this work through the use of their flume. This work is a contribution to the ELOISE Programme (ELOISE No. 214) in the framework of the ECOFLAT (Eco-Metabolism of a Tidal Flat) project carried out under contract ENV4-ct96-0216, jointly sponsored by the ENVIRONMENT and MAST programmes of the EU.

\section{LITERATURE CITED}

Asmus RM, Asmus H (1991) Mussel beds: limiting or promoting phytoplankton? J Exp Mar Biol Ecol 148:215-222

Baillie PW, Welsh BL (1980) The effect of tidal resuspension on the distribution of intertidal epipelic algae in an estuary. Estuar Coast Mar Sci 10:165-180

Barlow RG, Mantoura RFC, Gough MA, Fileman TW (1993) Pigment signatures of the phytoplankton composition in the northeastern Atlantic during the 1990 spring bloom. Deep-Sea Res Part II Top Stud Oceanogr 40:459-477

Cadée GC, Hegeman J (1974) Primary production of phytoplankton in the Dutch Wadden Sea. Neth J Sea Res 8: 240-259

Cloern JE, Powell TM, Huzzey LM (1989) Spatial and temporal variability in South San Francisco Bay (USA). II. Temporal changes in salinity, suspended sediments, and phytoplankton biomass and productivity over tidal time scales. Estuar Coast Shelf Sci 28:599-613

de Jonge VN, van Beusekom JEE (1992) Contribution of resuspended microphytobenthos to total phytoplankton in the Ems estuary and its possible role for grazers. Neth J Sea Res 30:91-105

de Jonge VN, van Beusekom JEE (1995) Wind- and tideinduced resuspension of sediment and microphytobenthos in the Ems estuary. Limnol Oceanogr 40:766-778

de Jonge VN, van den Bergs J (1987) Experiments on the resuspension of estuarine sediments containing benthic diatoms. Estuar Coast Shelf Sci 24:725-740

Delgado M, de Jonge VN, Peletier H (1991) Experiments on resuspension of natural microphytobenthos populations. Mar Biol 108:321-328

Demers S, Therriault JC, Bourget E, Bah A (1987) Resuspension in the shallow sublittoral zone of a macrotidal estuarine environment: wind influence. Limnol Oceanogr 32: 327-339

Eppley RW, Holmes RW, Strickland JDH (1967) Sinking rate of marine phytoplankton measured with a fluorometer. J Exp Mar Biol Ecol 1:191-208

Eppley RW, Reid FMH, Strickland JDH (1970) Estimates of 
phytoplankton crop size, growth rate, and primary production. In: Strickland JDH (ed) The ecology of the plankton off La Jolla, California, in the period April through September, 1967. Bull Scripps Inst Oceanogr 17:33-42

Estrada M, Berdalet E (1997) Phytoplankton in a turbulent world. Sci Mar 61(Suppl 1):125-140

Fréchette M, Bourget E (1985) Energy flow between the pelagic and benthic zones: Fcators controlling particulate organic matter available to an intertidal mussel bed. Can J Fish Aquat Sci 42:1158-1165

Graf G, Rosenberg R (1997) Bioresuspension and biodeposition: a review. J Mar Syst 11:269-278

Grøntved J (1949) Investigations on the phytoplankton in the Danish Waddensea in July 1941. Meddr Danm Fisk Havunders 5:1-55

Harris GP (1980) Temporal and spatial scales in phytoplankton ecology. Mechanisms, methods, models and management. Can J Fish Aquat Sci 37:877-900

Herman PMJ, Middelburg JJ, van de Koppel J, Heip CHR (1999) Ecology of estuarine macrobenthos. Adv Ecol Res 29:195-240

Herman PMJ, Middelburg JJ, Widdows J, Lucas CH, Heip CHR (2000) Stable isotopes as trophic tracers: combining field sampling and manipulative labelling of food resources for macrofauna. Mar Ecol Prog Ser 204:79-92

Hillebrand H, Durselen CD, Kirschel D, Pollingher U, Zohary $\mathrm{T}$ (1999) Biovolume calculation for pelagic and benthic microalgae. J Phycol 35:403-424

Hummel H (1985) Food intake of Macoma balthica (Mollusca) in relation to seasonal changes in its potential food on a tidal flat in the Dutch Wadden Sea. Neth J Sea Res 19: $52-76$

Kang CK, Sauriau PG, Richard P, Blanchard GF (1999) Food sources of the infaunal suspension-feeding bivalve Cerastoderma edule in a muddy sandflat of Marennes-Oléron Bay, as determined by analysis of carbon and nitrogen. Mar Ecol Prog Ser 187:147-158

Kiørboe T (1993) Turbulence, phytoplankton cell size, and the structure of pelagic food webs. Adv Mar Ecol 29:1-72

Kromkamp J, Peene J, van Rijswijk P, Sandee A, Goosen N (1995) Nutrients, light and primary production by phytoplankton and microphytobenthos in the eutrophic, turbid Westerschelde estuary (The Netherlands). Hydrobiologia 311:9-19

Lucas CH, Holligan PM (1999) Nature and ecological implications of algal pigment diversity on the Molenplaat tidal flat (Westerschelde estuary). Mar Ecol Prog Ser 180:51-64

Lucas CH, Widdows J, Brinsley MD, Salkeld PN, Herman PMJ (2000) Benthic-pelagic exchange of microalgae at a tidal flat. 1. Pigment analysis. Mar Ecol Prog Ser 196: 59-73

MacIntyre HL, Cullen JJ (1996) Primary production by suspended and benthic microalgae in a turbid estuary: time-

Editorial responsibility: Otto Kinne (Editor),

Oldendorf/Luhe, Germany scales of variability in San Antonio Bay, Texas. Mar Ecol Prog Ser 145:245-268

Mantoura RFC, Llewellyn CA (1983) The rapid determination of algal chlorophyll and carotenoid pigments and their breakdown products in natural waters by reverse-phase high-performance liquid chromatography. Anal Chim Acta 151:297-313

Moens T, van Gansbeke D, Vincx M (1999) Linking estuarine intertidal nematodes to their suspected food. A case study from the Westerschelde estuary (south-west Netherlands). J Mar Biol Assoc UK 79:1017-1027

Munk WH, Riley GA (1952) Absorption of nutrients by aquatic plants. J Mar Res 11:215-240

Muschenheim DK, Newell CR (1992) Utilization of seston flux over a mussel bed. Mar Ecol Prog Ser 85:131-136

Roman MR, Tenore KR (1978) Tidal resuspension in Buzzards Bay, Massachusetts. I. Seasonal changes in the resuspension of organic carbon and chlorophyll a. Estuar Coast Mar Sci 6:37-46

Shaffer GP, Sullivan MJ (1988) Water column productivity attributable to displaced benthic diatoms in well-mixed shallow estuaries. J Phycol 24:132-140

Smayda TJ (1970) The suspension and sinking of phytoplankton in the sea. Oceanogr Mar Biol Annu Rev 8:353-414

Smetacek VS (1985) Role of sinking in diatom life-history cycles: ecological, evolutionary and geological significance. Mar Biol 84:239-251

Sournia A (1982) Form and function in marine phytoplankton. Biol Rev 57:347-394

van Spaendonk JCM, Kromkamp JC, de Visscher PRM (1993) Primary production of phytoplankton in a turbid coastal plain estuary, the Westerschelde (The Netherlands). Neth J Sea Res 31:267-279

Wainwright SC (1990) Sediment-to-water fluxes of particulate material and microbes by resuspension and their contribution to the planktonic food web. Mar Ecol Prog Ser 62: $71-281$

Widdows J, Brinsley MD, Bowley N, Barrett C (1998a) A benthic annular flume for in situ measurement of suspension feeding/biodeposition rates and erosion potential of intertidal cohesive sediments. Estuar Coast Shelf Sci 46: $2-38$

Widdows J, Brinsley MD, Elliott M (1998b) Use of in situ flume to quantify particle flux (deposition rates and sediment erosion) for an intertidal mudflat in relation to changes in current velocity and benthic macrofauna. In: Black KS, Paterson DM, Cramp A (eds) Sedimentary processes in the intertidal zone. Geological Society, London, p 85-97 (Spec Publ No. 139)

Widdows J, Brinsley MD, Salkeld PN, Lucas CH (2000) Influence of biota on spatial and temporal variation in sediment erodability and material flux on a tidal flat (Westerschelde estuary). Mar Ecol Prog Ser 194:23-37

Submitted: May 19, 2000; Accepted: August 22, 2000

Proofs received from author(s): January 15, 2001 